\title{
INTERACTIVE METHODS AS MEANS OF ENSURING CONTINUOUS PROFESSIONAL DEVELOPMENT
}

\author{
Olga Soloviova \\ Associate Professor, Chernivtsi National University named after Yurii Fedkovych, Ukraine \\ e-mail: poloskotun@gmail.com,orcid.org/0000-0002-3758-5925 \\ Iryna Trefanenko \\ Associate Professor, Bukovinian State Medical University, Ukraine \\ e-mail: ira.trefanenko@gmail.com,orcid.org/0000-0002-7751-9412
}

\section{Summary}

The present paper aims at discussing the role of interactive methods in modern approach towards continuous professional development of medical students. Inner and outer reasons for switching from a traditional model of education to an innovative one caused popularuty of blended education among teachers. Pandemic situation as well as change of education focus from simple acquiring knowledge to getting real life and professional competencies prompt teachers to use new approaches to realization of their students' potential. We consider interactive methods to be the most effective and valuable for the modern specialist education due to their potential in terms of accessebility and engagement. To succeed in achieving aims of modern education teachers should ensure that methods they choose are activity and personality-oriented, systematic and complex, synergetic and competence-oriented. The research highlights merits of interactive approach and suggests possibile ways of usage on the example of a topic from the course of Internal Diseases for medical students.

Keywords: blended education, interaction, participatory learning, cooperative learning, hands-on/real life and professional competencies

DOI: https://doi.org/10.23856/4516

\section{Introduction}

The rapid development of information and communications technologies, their significant potential in almost every sphere of life of mankind have changed the learning processes considerably for all segments of the population. Starting from a school desk, people today cannot imagine themselves without the Internet. The latter has probably become another dimension of human existence. This quick introduction of modern technologies in the educational process contributes to the development of new perspectives in the continuous professional development of a specialist in any profession. Given the present-day conditions of higher education institutions in 2021 (long-term quarantine related to COVID-19), there should be changes in traditional approaches to the provision of educational services, their improvement and modernization. Therefore, the modern educational process is being organically transformed into a mixed or blended model of learning. Blended learning means a purposeful process of acquiring knowledge, skills and abilities carried out by educational institutions of various types within the framework of formal education, part of which is implemented remotely using information and communication technologies and teaching aids used for storing and delivering educational material, implementation of control measures, organization of interaction between participants (Bugajchuk, 2016). 


\section{Main Principles of Blended Learning}

We understand that the focal points of blended learning are the student and the teacher, and this process aims to create effective interaction of students within the frames of "student-content", "student-teacher" and "student-student". However, if in the traditional learning process all types of interaction are organized by the teacher in the process of live communication, and any deviations are regulated by direct contact, in e-learning students are mostly left alone with the content of the course. Indirect and asynchronous nature of the interaction, lack of live communication and of verbal (intonation, tone of voice) and nonverbal (facial expressions, gestures) means of communication lead to an urge to form new mechanisms of teacher influence on the educational process to ensure the quality of learning. The emphasis in ensuring the effectiveness of e-learning is transferred to a specially organized by the teacher learning environment - e-learning course, in the development of which it is necessary to simulate real learning conditions - to provide conditions for all types of learning interaction, as well as the effect of constant teacher presence.

So the role of the teacher:

- to ensure the principle of trust in communication. To achieve this objective a teacher may use a special organization of group space during classes: usually, students and teacher are placed in a circle facing each other, to change students' stereotypes and ideas about how classes should be conducted and organized and which role the teacher should play.

- to ensure the principle of equality. It means that the teacher does not try to impose his thoughts on the students, but acts together with them. In turn, each student has the opportunity to play the role of organizer and leader.

Our society requires not only highly qualified workers but also those who can think independently, critically and creatively, being responsible, mobile, competitive and professionally competent, capable of self-development and self-realization. Increasingly, employers are demanding that their employees have not only professional skills but also certain personal characteristics and qualities.

Thus, for more and more people, higher education today becomes not just a means of professional training in various fields, but a mandatory stage of personal development, which is a hallmark of our time. Analysis of recent publications and researches of scientists, as well as opinions of university professors, students and employers allowed to develop a model of the personality of a specialist with higher education with relevant characteristics, knowledge and competence:

- High-quality training of a certain profession within the model of general higher education development.

- Striving for constant updating of knowledge and new skills in the field of professional interests, conviction in the need for continuous training and improvement.

- Ability to self-assess objectively, self-develop, the need for achievement and independent decision-making, flexibility and confidence in the application of knowledge in non-standard conditions.

- Timely adaptation to rapidly changing living and professional conditions.

- High social activity in all spheres of life, competitiveness in social and economic activities.

- Availability of knowledge and skills in the field of modern information technologies, namely: obtaining information from various sources, its critical interpretation, systematization, preservation, analysis and creative use. 
- Proficiency in several foreign languages at the level of communication and performance in any audience.

- Ability to work effectively in a group, tolerance and emotional balance.

- Formation of universal and national values.

- Skills to present the result in different forms and types.

Requirements for professionalism and personality of the specialist have prompted to seek new paradigms for reforming education, its new models and technologies, innovative approaches, forms and methods of teaching (Pometun, Pyrozhenko, 2004).

\section{Interactive Methods in Blended Learning}

Among the learning models are: traditional or classical, active and interactive. The peculiarities of the traditional (classical) model are that students learn from the teacher (traditional lectures) or from the textbook, do not participate in the discussion, and in practical classes are interviewed on the theoretical lesson plan and students demonstrate only reproductive knowledge. The peculiarities of the active model involve the stimulation of cognitive activity and independence of students, interaction in the system of student-teacher, as well as the presence of creative tasks.

This method includes: debates, open microphone, information search, implementation of individual creative projects, quizzes, crossword puzzles, others. Unlike active methods, interactive methods are focused on the wider interaction of students not only with the teacher, but also with each other, with the emphasis on the dominance of student's participation in the learning process. The role of the teacher in interactive classes is to direct students to achieve the goals of the lesson.

Interactive learning is a specific form of organization of cognitive activity, which has a predictable goal - to create a comfortable learning environment in which each student feels personal success and intellectual ability (Pometun, Pyrozhenko, 2004). The word "interactive" from inter (from Latin among, between, betwixt, in the midst of) and act (from Latin "do, perform") means to be able to interact, to hold a dialogue. The basis of this technique is organized creative cooperation of equal individuals. All students and teachers actively interact with each other, analyze their own actions and the actions of other participants in the learning process, and subsequently change their behavior.

The student and the teacher are equal participants of the learning process. The approach to the student, which is at the center of the learning process, is based on respect for his opinion, on the motivation for activity, on the encouragement of creativity. It consists primarily of increasing the educational efficiency of classes, of a significant increase in the level of implementation of the principles of consciousness, activity and quality of knowledge, skills and abilities acquired by students. This new approach is called "participatory learning", "cooperative learning", which provides an opportunity to comprehensively discuss each problem, prove and justify their views on how to solve it.

This contributes not only to a deeper understanding of the educational material, but also to the development of thinking and speaking. The teacher during the interactive learning acts as an organizer of the learning process, a consultant. That is, the teaching process becomes a process of learning first of all controlled by the teacher and by students (Gusak, 2019).

Interactive learning has many advantages over a traditional mode. Researchers have found that no more than $20 \%$ of information is assimilated during a lecture, while $75 \%$ is learned in a discussion process and about $90 \%$ in a reproduction mode. Scientists and practitioners have 
proven and widely recognized that interactive learning is an effective method of stimulating interest in learning and motivation of educational and cognitive activities and promotes:

- mastering different stages of educational activities;

- critical thinking development;

- growth of self-confidence;

- development of independence;

- the formation of a positive self-concept;

- development of creativity;

- formation of organizational and communication skills;

- formation of relevant hands-on/real life and professional competencies;

- increasing success.

\section{Realization of Interactive Approach}

The following approaches form the methodological basis of interactive learning:

- Activity approach, the main thesis of which, regarding the development of personality, is that a person discovers the properties and connections of the elements of the real world only in the process of activity and on the basis of its various types. Scientists have proven that the student can cope with material better if they are aware of what is the aim of their activity. Therefore, conscious learning involves, on the one hand, the implementation of appropriate actions by the teacher with the learning material, not just its observation and listening, on the other - the transformation of the material into the main purpose of these actions, i.e. solving learning problems. According to the activity approach, the stages of knowledge acquisition are considered to be the stages of activity acquisition. The process of learning from the standpoint of didactics is organized by the teacher or the student into a purposeful, self-directed, reflective and transformative activity for the acquisition of knowledge.

- Personality-oriented approach. One of the aspects of the modern reformation of national education is the mastery of a new philosophy of education and methodological reorientation of the educational process to the development of personality, the formation of its basic professional competencies. The basis of personality-oriented education is humanization. Focusing the high school on the student's personality, showing respect and trust in them, understanding their needs, interests, goals impact the process of their formation. The humanization of the educational process is realized, in particular, through the consistent individualization of the pedagogical process - the content, methods and forms of teaching and learning. It presupposes the responsibility for the available experience and level of students' achievements, the orientation of the personality, and interests. Personality-oriented education is not the formation of a personality with predetermined properties, but the provision of favourable conditions for the full identification and development of the personal functions of the student.

- Systematic approach includes the fact that knowledge is built in the minds of students according to the following sequence: basic scientific concepts - the main provisions of the theory - consequences - application. Therefore, students need to be equipped not only with factual knowledge of theory but also with methodological knowledge, i.e. knowledge about the most important elements of knowledge and structural connections between them. In this case, the elements of knowledge are knowledge that is characterized by relative independence, those that in the learning process become the object of study, or a means of solving theoretical, practical or educational problems. 
- A complex approach provides a thorough, strong system of knowledge. This approach is a consequence of the application of the law of dialectics, according to which each phenomenon should be considered in all of its connections and mediations.

- Synergetic approach. This scientific direction of the theory of self-organization formulates the principles of self-organization, which operate at all structural levels of matter. A modern scientific paradigm that combines knowledge about systemic nature and man, the functioning of complex systems, matter and spirit, on the methodological basis of which a significantly new picture of the world is created. The technique provides a person with many opportunities for self-development within socio-cultural norms. The task of education in this context is to involve the individual in the social and humanistic path of their possible development.

- Competence approach determines the focus of the educational process on the formation and development of key hands-on/real life and professional competencies of the individual. It strengthens the actual practical orientation of education and focuses on its results.

Today in high schools use the following interactive methods: workshops, situational tasks, master classes, press conferences, testing, case methods, game trainings, round tables, world cafes, multimedia lectures and practical classes, electronic educational publications. All of them help to form the real life potential of future professionals (Ostapchuk, Myronchuk, 2014).

Interactive learning in the structure of blended education helps to: create educational materials for a visual demonstration of educational information; store them within specially designated resources, with the ability to quickly access them; control and correct knowledge and skills acquired in the learning process; build an individual scenario of conducting lessons; access information from various online resources on personal mobile devices at any time. Internet services provide the ability to use, process and transmit data regardless of the location of the specialist while providing communication between participants in the educational process (Gulivata, Bondar, 2019).

Here is an example of a lesson for graduates:

Round Table (group discussions) on "Management of a Patient with Edema Syndrome". Mini-presentation of the teacher on the main points of the topic with the help of multimedia Internet presentations (Prezi, SlideShare, SlideBoom, PowToon, Emaze, Prezentit, Menti, etc.). A teacher divides students into groups in breakout rooms of the electronic platform; distributes cards for assessing groups. Groups are invited to get ready with questions according to the topic (diseases that co-occur with edema) in the form of an online poster, business card or video message (Glogster, VectorPaint, ThingLink, etc.). After each group's presentation, other students ask questions. After discussing reports, a unified approach to the tactics of examining and treating patients is formed, in parallel involving studying Internet resources with guidelines, protocols, orders and recommendations of societies of Ukraine, Europe and America (Jamboard, Padlet). Separately, a teacher can offer to prepare a detailed clinical task to visualize the topic. It is also proposed to take a test final control on such platforms as Edmodo.com, Quizlet.com, Kahoot. com, Moodle.com, etc. A teacher summarizes making comments and arguing their conclusions.

\section{Conclusions}

Thus, the use of various forms of interactive learning is a promising direction to ensure the introduction of blended learning in the system of higher education institutions, especially for the continuous professional development of specialists, including doctors and pharmacists. Interactive methods offer a purposeful process of acquiring knowledge, skills and abilities 
carried out by educational institutions of various types within the framework of continuous education, part of whichmay be implemented remotely using information and communication technologies and teaching aids. They ensure participatory and cooperative learning, help develop hands-on/real life and professional competencies and improve students engagement.

\section{References}

Bugajchuk K.L. (2016). Zmishane navchannya: teoretychnyj analiz ta strategiya vprovadzhennya $v$ osvitnij proces vyshhyx navchalnyx zakladiv [Blended learning: theoretical analysis and strategy of introduction of higher educational institutions into the educational process]. Informacijni texnologiyi $i$ zasoby navchannya - Information texnologiyi and zasoby navchannya, 4 (54), 1-18 [in Ukrainian]. http://nbuv.gov.ua/UJRN/ITZN_2016_54_4_3.

Pometun O.I., Pyrozhenko L.V. (2004) Suchasnyj urok. Interaktyvni texnologiyi navchannya: naukovo-metodichniy posibnyk [Interactive learning technologies: scientific-methodical manual] K.: Vydavnycztvo A.S.K [in Ukrainian]. https://www.twirpx.com/file/357881/

Gusak L.P. (2019) Interaktyvni metody navchannya u procesi vyvchennya vyshhoyi matematyky`studentamy ekonomichnyx specialnostej. Interaktyvnyj osvitnij prostir ZVO [Interactive teaching methods in the process of studying higher mathematics by students of economic specialties. Interactive educational space ZVO] : Materialy vseukrayinskogo naukovo-praktychnogo vebinaru, 9-12. Retrieved from http://www.vtei.com.ua/images/2019/KF/04_03_2019zb. pdf [in Ukrainian].

Ostapchuk D., Myronchuk N.M. (2014) Interaktyvni metody navchannya u vyshhyx navchalnyx zakladax [Interactive teaching methods in higher education institutions] S.S. Vitvyczkoyi (Eds.), Modernizaciya vyshhoyi osvity v Ukrayini ta za kordonom - Modernization of higher education in Ukraine and abroad: zbirnyk naukovyx pracz (pp. 140-143) [in Ukrainian]. http:// eprints.zu.edu.ua/id/eprint/13837

Gulivata I.O., Bondar M.V. (2019) Metodychnyj aspekt vprovadzhennya zmishanogo navchannya u zakladax osvity Interaktyvnyj osvitnij prostir ZVO [Methodical aspect of introduction of blended learning in educational institutions Interactive educational space of ZVO]. Materialy vseukrayinskogo naukovo-praktychnogo vebinaru, 7-9. Retrieved from http://www.vtei.com.ua/ images/2019/KF/04_03_2019zb.pdf [in Ukrainian]. 